Open Access

\title{
Childhood economic status predicting later income: the role of networking ability and encouragement of participation
}

\author{
Kun Yu and Yuhui Li
}

\author{
* Correspondence: \\ Yuhui_li@ruc.edu.cn \\ School of Labor and Human \\ Resources, Renmin University of \\ China, Beijing 100872, China
}

\begin{abstract}
Drawing from a social capital perspective, this study examines the psychological mechanism and boundary conditions of the relationship between individuals' childhood economic status (CES) and later income. Specifically, we tested the mediating role of networking ability and the moderating role of encouragement of participation in this relationship. With a sample of 3635 employees in China and the use of multistage stratified sampling, the results indicate that networking ability mediates the CES and later income relationship. Moreover, encouragement of participation acts as a necessary condition in the relationship between networking ability and later income. Specifically, when encouragement of participation was high, increased networking ability was associated with increased later income. When encouragement of participation was low, the positive relationship between employees' networking ability and later income was no longer significant. Finally, the indirect effect of CES on later income mediated by networking ability was stronger for organizations with a higher level of encouragement of participation. Findings and future directions in the theory and practice of career development are discussed.
\end{abstract}

Keywords: Career success, Economic status, Networking ability, Encouragement of participation

\section{Background}

There has been a long history of investigation into the antecedents of individuals'career success (Seibert, Crant, \& Kraimer, 1999). As a critical indicator of career success, income has drawn excessive attention from researchers in the organizational behavior field for years, especially the examination of its predictors (Ng \& Feldman, 2014), including proactive personality (Seibert, Kraimer, \& Crant, 2001), political behavior (Judge \& Bretz, 1992) and demographic variables such as gender (Ng, et al., 2005). As well, some researchers have been interested in the relationship between individuals' early experience and their later income (Duncan et al., 1998). For instance, childhood economic status (CES) has been found to be a critical predictor of later income in a series of studies (e.g., Gibb, Fergusson, \& Horwood, 2012; Hobcraft \& Kiernan, 2001).

However, while the relationship between CES and later income is well established, the psychological processes underlying this relationship has been, however, poorly investigated. Prior research has not examined how individuals' early economic status

(c) The Author(s). 2018 Open Access This article is distributed under the terms of the Creative Commons Attribution 4.0 International License (http://creativecommons.org/licenses/by/4.0/), which permits unrestricted use, distribution, and reproduction in any medium, provided you give appropriate credit to the original author(s) and the source, provide a link to the Creative Commons license, and indicate if changes were made. 
influences their cognition, attitudes and behavior, which in turn have an impact on their career success. In addition, boundary conditions of the CES-later income relationship has also not been adequately investigated, especially for organizational boundary conditions. There is a dearth of research examining the situation influence on the relationship between CES and later income in work settings. A deeper understanding of how and when CES has a stronger (or weaker) effect on later income will not only contribute to the literature on career development but also allow organizations to better promote individuals' career success.

To address this void, the current study draws upon a social capital perspective (Lin, 1999, 2002) and tests the psychological mechanism and boundary conditions in the relationship between CES and later income. First, we conceptualize networking ability as a type of ability to accumulate social capital and test its mediating effect on the relationship between childhood economic status (CES) and later income to gain insight into the social capital-based mechanisms of this relationship. Moreover, by framing encouragement of participation as an advantageous environment for social capital building, and examining the moderating role of encouragement of participation in the CESlater income relationship, we aim to demonstrate that the effect of CES on later income through networking ability is not universal across all organizations, but depends on the level of encouragement of participation in that organization. The investigation of boundary conditions would not only answer the question as to whether the impact of employees' networking ability on their career success depends on organizational conditions, but also helps us to gain a better understanding of the contingent nature of the CES-later income relationship.

\section{Theoretical foundation and hypothesis development Mediating role of networking ability}

Networking ability refers to individuals' ability to build and maintain large and strong social networks (Burt, 2009). While the network they build contains some influential others, employees with high networking abilities are expected to possess information asymmetries (Burt, 2009), be connected to significant others and be in a position to generate and receive more opportunities (Pfeffer, 1992), which will help them achieve their goals (Ferris et al., 2007, 2008; 2012). Of the four dimensions of political skills (i.e., networking ability, social astuteness, interpersonal influence, and apparent sincerity), networking ability was found to be the strongest in predicting career and organizational outcomes (Todd et al., 2009). For example, networking ability was found to be the only predictor of employees' total compensation among four political skill dimensions (Ferris et al., 2008; Todd et al., 2009). Thus, from the perspective of individuals within the social network, it is of great importance for them to have the ability to network and use it to construct a network that is beneficial to their career success (Thompson, 2005).

According to social capital theory, social capital can be defined as the "sum of actual and potential resources embedded within" a social network (Nahapiet \& Ghoshal, 1998). The process of networking, which is defined as developing a strong network that is useful (Ferris et al., 2012), can be conceptualized as a typical type of social capital accumulation. Therefore, networking ability can be captured as the ability to engage in social capital acquisition. It is reasonable to argue that individuals from families with better economic 
situations would have more opportunities, such as better education (Masters, 1969), to develop various abilities, including networking abilities. As a result, it may be easier for high CES individuals rather than low CES individuals to obtain a high level of networking ability. For individuals with a higher level of networking ability, they would gain more social capital through an effective process of network-building, including information accessing and influence wielding (Thompson, 2005). Given the close association between social capital and career success (Seibert, Kraimer, \& Liden, 2001), such as income level (Robison \& Siles, 1999), a higher level of social capital will in turn help individuals to achieve more career success such as a higher level of income. In sum, we predict that:

Hypothesis 1: Networking ability mediates the positive relationship between CES and later income.

\section{Moderating role of encouragement of participation}

Since networking ability is characterized by social effectiveness (Blickle et al., 2009), environmental factors may play a key role in affecting the impact of networking ability on career outcomes. However, to date, few studies have tapped into the contextual influence in the networking-career success relationship. Based on social capital theory (Lin, 1999, 2002; Nahapiet et al., 1998), resources or capital are embedded within relationships, which is created through exchange with others (Bourdieu, 1986). Since the exchange does not happen in a vacuum but in real organizational settings, situational factors affecting the quality and quantity of exchange, such as the encouragement of participation (Sun et al., 2007), may have an impact on the accumulation of social capital.

Encouragement of participation, which refers to the degree that the organization encourages employees to make decisions on their own work and participate in decisions regarding the organization (Bamberger, Biron, \& Meshoulam, 2014; Bamberger \& Meshoulam, 2000; Sun et al., 2007), is a typical organizational condition that promotes leader-subordinate exchange. Thus, we conceptualize encouragement of participation as creating an advantageous environment for social capital accumulation. Organizations with a high level of encouragement of participation provide employees with opportunities to have smooth communication with leaders and give suggestions to improve their performance (Bamberger et al., 2014; Bamberger \& Meshoulam, 2000; Sun et al., 2007). From a social capital perspective (Lin, 1999, 2002), networking processes require employees to connect to influential people and be in a position where it is easy to generate and receive opportunities (Pfeffer, 1992). A high level of encouragement of participation would provide a favorable environment for employees to exert influence and receive opportunities. Thus, employees with a high level of encouragement of participation are more likely to utilize their ability to network to achieve career success (e.g., high income) than in a low-participation environment. Therefore, we propose that encouragement of participation will moderate the relationship between employee networking ability and later income. Specifically, when encouragement of participation is high, an increase in networking ability will be associated with increased income. When encouragement of participation is low, the positive relationship between networking ability and income will be attenuated.

As noted above, networking ability was expected to mediate the relationship between CES and later income. Hence, encouragement of participation is expected to moderate the indirect effect of CES on later income via networking ability (a moderated 
mediation model) as displayed in Fig. 1. When an organization encourages participation, the positive relationship between employees' CES and their later income mediated through networking ability will be stronger. This leads to our second hypothesis:

Hypothesis 2: Encouragement of participation moderates the relationship between employees' CES and their later income mediated through networking ability. Specifically, the positive relationship between networking ability and later income is stronger when encouragement of participation is high.

\section{Method}

\section{Participants and procedures}

We collected data from a national survey program for human resources management in China. The content of the survey includes questionnaires on human resources management, labor relations and social security. The survey program was implemented in 12 cities across the country. The selection of cities was based on geographical distribution and population. Next, the survey program selected companies through two-step stratified random sampling from companies listed in the Index of the National Companies in China 2008 and located in the 12 cities. In the first step, 36,000 companies in 12 cities were randomly selected. In the second step, 444 of the 36,000 companies were randomly selected to administer the survey to their 4532 employees. Finally, 3635 employees completed the whole survey, with a response rate of $80 \%$. Among the 3635 participants, 1978 were female (54.4\%), 1657 were male (45.6\%), the average age was 33.39 $(\mathrm{SD}=9.35), 28.7 \%$ of them had a college degree, and $24.4 \%$ of them had a bachelor degree or above. The majority of the participants (57.0\%) were front-line workers, $24.6 \%$ were business or technical staff, and $18.4 \%$ were managers.

\section{Measures}

\section{Childhood economic status}

CES was measured by one item question about the participants' socioeconomic status at the age of 14 . The question is "How was your family income comparing to the average level when you were 14?". Participants were asked to rate their answer on a 5-point scale ( 1 = significantly worse than average, $5=$ significantly better than average).

\section{Later income}

Later income was measured by employees' self-reported annual income using two items, which were "How much was your salary last year" and "How much did you

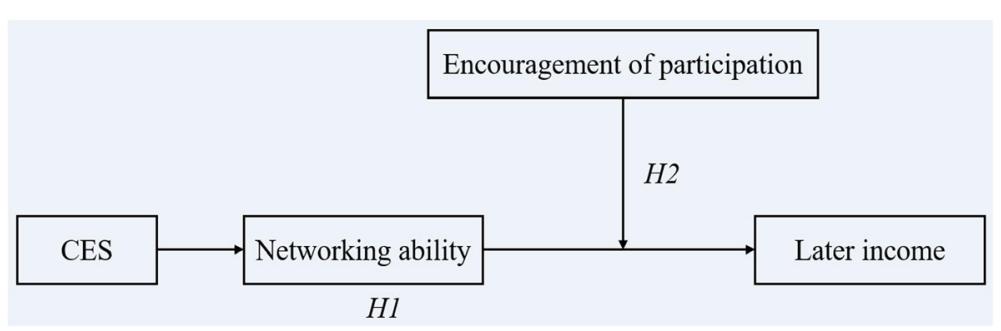

Fig. 1 Childhood economic status (CES) and later income: the mediating role of networking ability and moderating role of encouragement of participation 
receive in supplementary income (e.g., bonuses, profit-sharing, awards) last year?" The later income was obtained by the sum of the respondent's scores for the two items. A self-reported measure of income, which has been shown to have a high correlation with organization records (Dreher, 1977), can be a valid measure of income for this study.

\section{Networking ability}

Networking ability was measured by the networking ability dimension of Ferris et al.'s (2005) 18-item political skill scale. Participants were asked to rate their agreement about their networking ability on a 5 -point scale $(1=$ strongly disagree, $5=$ strongly agree). A sample item is "I spend a lot of time and effort at work networking with others." Higher scores represent a higher ability in networking. Cronbach's $\alpha$ for networking ability was 0.78 .

\section{Encouragement of participation}

Encouragement of participation was measured by the 4-item participation dimension of the high-performance human resource practice scale (Sun et al., 2007). Respondents were asked to rate their agreement with statements related to their perceived encouragement of participation within the organization on a 5-point scale $(1=$ strongly disagree, 5 = strongly agree). The items are: "Employees in this job are often asked by their supervisor to participate in decisions"; "Individuals in this job are allowed to make decisions"; "Employees are provided the opportunity to suggest improvements in the way things are done"; and "Supervisors keep open communications with employees in this job". Higher scores represent a higher level of encouragement of participation. Cronbach's $\alpha$ for encouragement of participation was 0.80 .

\section{Control variables}

Participants' demographic characteristics, including gender $(1=$ male, $2=$ female), age, education level ( 1 = illiteracy, 2 = primary school, $3=$ middle school, $4=$ high school, 5 = technical secondary school, $6=$ college, $7=$ bachelor, $8=$ master or above), tenure (measured in years), job position ( 1 = front-line workers, $2=$ business or technical staff, $3=$ managers $)$ and nature of the organization they belong to $(1=$ stated-owned company/ public sector, 2 = private firms), were measured as control variables.

\section{Data analysis}

To examine the role of encouragement of participation in the relationship between networking ability and income, we adopted the "second stage moderation model"approach (Edwards \& Lambert, 2007), which refers to the model with a moderating effect on the second path of the indirect effect of the independent variable on the dependent variable through the mediator. In our model, networking ability plays a mediating role in the relationship between CES and later income, and encouragement of participation moderates the path from networking ability to later income. Thus, there is a conditional indirect effect of CES on later income at different levels of encouragement of participation. We used Model 14 (second stage moderated mediation model) from Hayes' (2013) PROCESS macro in SPSS to complete the data analysis. 


\section{Results}

\section{Preliminary analysis}

To ensure the discriminant validity of the self-rated variables (networking ability and encouragement of participation), a confirmatory factor analysis (CFA) was performed using Mplus 7 (Muthén and Muthén, 1998-2012). The two-factor model (i.e., both variables are independent of each other) provided a generally good fit to the data, with $\chi^{2}(26)=698.84, p<0.01$, comparative fit index $(\mathrm{CFI})=0.93$, TuckerLewis index $(\mathrm{TLI})=0.90$, and root-mean-square error of approximation $(\mathrm{RMSEA})=$ 0.08. According to the chi-square difference tests, the two-factor model fit the data significantly better than the one-factor model (i.e., combining Networking ability and Encouragement of participation for active divergence), $X^{2}(27)=3966.56, p<$ 0.01 , CFI $=0.57$, TLI $=0.43$, and $\mathrm{RMSEA}=0.20$. Thus, the discriminant validity of the study variables was supported.

\section{Descriptive statistics and correlations}

Table 1 presents the means, standard deviations, correlations, and scale reliabilities $(\alpha)$ of the study variables. As expected, Employees' CES was positively associated with their later networking ability $(r=0.06, p<0.01)$ and income $(r=0.10, p<0.01)$. Both employees' networking ability $(r=0.07, p<0.01)$ and perceived encouragement of participation $(r=0.09, p<0.01)$ were positively associated with their income too. Employees' gender $(r=-0.13, p<0.01)$ and age $(r=-0.07, p<0.01)$ were negatively correlated with their later income, while educational level positively correlated with their later income $(r=0.29, p<0.01)$. Employees' tenure had a negative correlation with their networking ability $(r=-0.04, p<0.05)$. Employees' job position was positively correlated with their networking ability $(r=0.09, p<0.01)$ and later income $(r=0.28, p<0.01)$, while nature of organization was positively associated with networking ability $(r=0.06, p<0.01)$.

Table 1 Means, standard deviations, and correlations

\begin{tabular}{llllllllllll}
\hline Variable & $M$ & SD & 1 & 2 & 3 & 4 & 5 & 6 & 7 & 8 & 9 \\
\hline 1. Gender & 1.54 & 0.50 & - & & & & & & & \\
2. Age & 33.39 & 9.35 & $-0.09^{* *}$ & - & & & & & & \\
3. Edu & 5.25 & 1.52 & $0.08^{* *}$ & $-0.38^{* *}$ & - & & & & & \\
4. Tenure & 7.49 & 6.44 & $-0.05^{* *}$ & $0.49^{* *}$ & $-0.10^{* *}$ & - & & & & \\
5. Job position & 1.61 & 0.78 & $-0.03^{*}$ & -0.00 & $0.28^{* *}$ & $0.07^{* *}$ & - & & & & \\
6. NOO & 1.72 & 0.45 & $0.04^{*}$ & $-0.11^{* *}$ & $-0.08^{* *}$ & $-0.32^{* *}$ & 0.02 & - & & & \\
7. CES & 2.84 & 0.65 & $0.09^{* *}$ & $-0.09^{* *}$ & $0.21^{* *}$ & -0.01 & $0.09^{* *}$ & $-0.05^{* *}$ & - & & \\
8. Networking ability & 3.20 & 0.67 & $-0.12^{* *}$ & $-0.04^{* *}$ & 0.03 & $-0.04^{*}$ & $0.09^{* *}$ & $0.06^{* *}$ & $0.06^{* *}$ & $(0.77)$ & \\
9. Encouragement of & 3.39 & 0.74 & $0.05^{* *}$ & $-0.11^{* *}$ & $0.07^{* *}$ & $-0.07^{* *}$ & $0.10^{* *}$ & $0.08^{* *}$ & $0.04^{*}$ & $0.26^{* *}$ & $(0.80)$ \\
participation & & & & & & & & & & & \\
10. Later income & $31.50 \mathrm{~K}$ & $19.22 \mathrm{~K}$ & $-0.13^{* *}$ & $-0.07^{* *}$ & $0.29^{* *}$ & -0.01 & $0.28^{* *}$ & 0.02 & $0.10^{* *}$ & $0.07^{* *}$ & $0.09^{* *}$ \\
\hline
\end{tabular}

$N=3635$. Reliability coefficients are reported along the diagonal. Gender was coded as follows: $1=$ male, $2=$ female; Educational level was coded as follows: $1=$ illiteracy, $2=$ primary school, $3=$ middle school, $4=$ high school, $5=$ technical secondary school, $6=$ college, $7=$ bachelor, $8=$ master or above; Tenure was measured in years; Job position was coded as follows: 1 = front-line workers, 2 = business or technical staff, 3 = managers; NOO: nature of organization, which was coded as follows: 1 = stated-owned company/ public sector, 2 = private firms; CES: childhood economic status. ${ }^{*} p<0.05,{ }^{* *} p<0.01$ 


\section{Hypothesis tests}

Hypothesis 1 proposed that networking ability mediates the CES-later income relationship. We examined the mediating effect of networking ability using Model 4 (mediation model) from Hayes' (2013) PROCESS macro in SPSS. With the bootstrapping of 5000 re-samples, the results show that the indirect effect of CES on later income through networking ability is significant (Estimates $=0.11, S E=0.04, p<0.05,95 \%$ confidence interval $(\mathrm{CI})=[0.04,0.21])$. After controlling for employees' gender, age, educational level, tenure, job position and nature of organization, the indirect effect of CES on later income through networking ability is still significant (Estimates $=0.05, S E=0.03, p<$ $0.05,95 \%$ confidence interval $(\mathrm{CI})=[0.00,0.12])$. Thus, Hypothesis 1 is supported.

We then examined Hypothesis 2 (moderated mediation hypothesis) following Preacher et al.'s (2007) recommended procedure. After controlling for employees' gender, age, educational level, tenure, job position and nature of organization, we examined the conditional indirect effect using Model 14 (second stage moderated mediation model) from Hayes' (2013) PROCESS macro in SPSS. With the bootstrapping of 5000 re-samples, as shown in Table 2, the results firstly show that the networking abilityencouragement of participation interactive effect on later income is significant (Estimate $=1.11, S E=0.51, p<0.05)$. Moreover, encouragement of participation significantly moderates the indirect effect of CES on later income via networking ability. Specifically, the indirect effect is $0.07(S E=0.04, p<0.05,95 \% \mathrm{CI}=[0.00,0.17])$ when encouragement of participation is high $(+1 S D)$ versus $-0.04(S E=0.04$, ns, 95\% CI $=[-0.13,0.02])$ when encouragement of participation is low $(-1 S D)$. The effect of the difference between the two conditions is $0.07(S E=0.04, p<0.05,95 \% \mathrm{CI}=[0.02,0.17])$, indicating that the moderating effect of encouragement of participation on the indirect effect is significant. In addition, we did a simple slopes test at \pm 1 standard deviation of encouragement of participation. The results are presented in Fig. 2. Networking ability is positively related to later income for employees with a high level of encouragement of participation (+1 SD; Estimate $=1.12, S E=0.57, p<0.05)$, but not significant for employees with a low level of encouragement of participation $(-1 S D$; Estimate $=-0.49$, $S E=0.62, n s)$.

Table 2 Regression results of hypothesized effects

\begin{tabular}{|c|c|c|c|c|}
\hline \multirow[t]{2}{*}{ Predictor } & \multicolumn{2}{|c|}{ Networking ability } & \multicolumn{2}{|c|}{ Later income } \\
\hline & Estimate & SE & Estimate & SE \\
\hline Gender & $-0.17^{* *}$ & 0.02 & $-5.51^{* *}$ & 0.60 \\
\hline Age & $0.00^{*}$ & 0.00 & 0.04 & 0.04 \\
\hline Edu & 0.00 & 0.01 & $3.06^{* *}$ & 0.22 \\
\hline Tenure & 0.00 & 0.00 & 0.03 & 0.06 \\
\hline Job position & $0.07^{* *}$ & 0.01 & $4.79^{* *}$ & 0.40 \\
\hline NOO & $0.08^{* *}$ & 0.03 & $1.93^{* *}$ & 0.70 \\
\hline CES & $0.06^{* *}$ & 0.02 & $1.36^{* *}$ & 0.47 \\
\hline NA & & & -3.51 & 1.81 \\
\hline EP & & & -1.94 & 1.65 \\
\hline$N A \times E P$ & & & $1.11^{*}$ & 0.51 \\
\hline$R^{2}$ & $0.03^{* *}$ & & $0.15^{* *}$ & \\
\hline
\end{tabular}

$N=3635$. Edu: educational level; NOO: nature of organization; CES: Childhood economic status; NA: networking ability; EP: encouragement of participation; $S E$ : standard error. ${ }^{*} p<0.05,{ }^{* *} p<0.01$ 


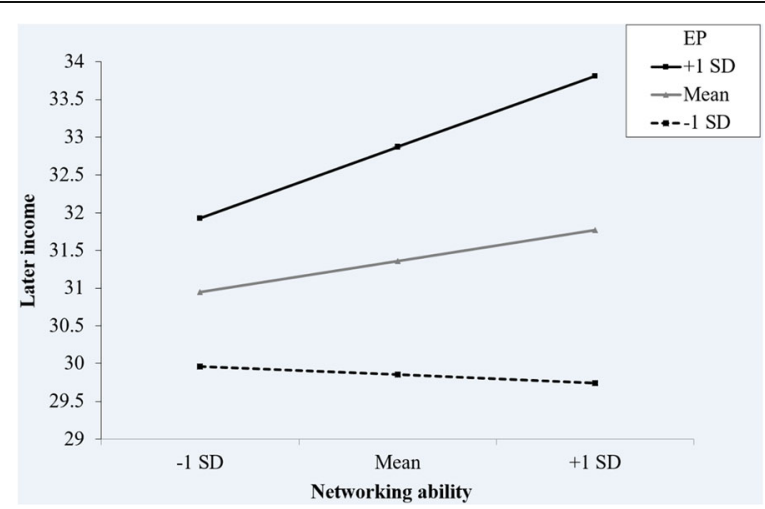

Fig. 2 Interaction between networking ability and encouragement of participation predicting later income. $\mathrm{SD}=$ standard deviation; $\mathrm{EP}=$ encouragement of participation

\section{Discussion}

\section{Contribution of the study}

By examining the mechanisms and moderators of the effect of CES on later income, the current study has made several contributions to theory and practice in career development and organizational behavior. Firstly, given the importance of the research of intergenerational income mobility (Solon, 1992) and deficient investigation of the psychological mechanisms of the relationship between CES and later income, the findings of the current study, which demonstrate that networking ability acts as a mediator, provide us a new possible route to understanding the CES-later income relationship. Second, the present study identifies encouragement of participation as a boundary condition in the networking ability-career success relationship and furthers the relationship between CES and later income mediated by networking ability. It is worth noting that normal and above-level encouragement of participation in organizations is a necessity for high-CES and networking ability employees to gain more income than their low-CES and networking ability colleagues. Under low levels of encouragement of participation, the positive relationship between networking ability and income becomes non-significant.

These findings are consistent with social capital theory (Lin, 1999, 2002), which posits that social capital is accumulated through exchange relationships. Individuals with high CES find it easier to develop and obtain a high level of networking ability, which in turn helps them accumulate more social capital and gain more career success. However, while a low level of encouragement of participation hinders employees from the exchange with coworkers and leaders, the efficacy of networking on social capital acquirement will be impaired. Without sufficient social capital, the career development (such as compensation growth) of even high CES employees will be impeded. Encouragement of participation here acts as an environmental requirement for employees to give full play to their networking abilities, part of which is derived from their CES.

The current study also contributes to the research and application of highperformance human resource practice (Bamberger et al., 2000; Sun et al., 2007). Although Sun et al. (Sun et al., 2007) claimed that high-performance human resource practice contains six sub-dimensions and encouragement of participation is one of the 
sub-dimensions, they had not examined the effect of its sub-dimensions on organizational and individual outcomes. The current study is the first to examine the situational influence of the encouragement of participation in career research. The findings of the moderating role of encouragement of participation in the networking ability-later income relationship will promote our understanding of the impact of organizational policy on individual career development.

\section{Limitations and future directions}

Although the current study contributes to the literature in several ways, there are certain limitations that should be noted in the present investigation. First, though the present study has a large sample of 3635 employees using multistage stratified sampling to examine the predicting effect of employees' CES on their career success and the mechanisms and moderators of this effect, the using of cross-sectional data limits the conclusions about the effect's direction and duration and may lead to common method bias. Future research should address this concern and use a time-lagged study design to give stronger evidence of the study effect.

Second, the current study only measures total compensation as a career success indicator. Although compensation acts as one of the most critical and objective elements of career success (Seibert et al., 1999), there are still other objective elements (i.e., promotion) and subjective elements (i.e., career satisfaction and life satisfaction) of career success that deserve further investigation. Future research could address this point, and the results will provide a complete picture of the interactive effect of networking ability and encouragement of participation on career success. Further, only one item was used to measure CES. Future research could use additional items to ensure the validity of CES measurement. In addition, future studies could also incorporate more control variables reflecting individuals' sociological status other than CES into the research model to better capture the unique effect of CES on career success.

Third, drawing upon social capital theory (Lin, 1999, 2002), we argue that networking ability mediates the relationship between CES and later income. Although the hypothesis was supported, much further work is needed into the investigation of the psychological mechanisms of the CES-later income relationship. For example, future research could draw from the interactionist perspective (Terborg, 1981) and examine the role of proactive personality in the CES-later income relationship. It will be even better to simultaneously consider multiple paths of mediation and examine which path could explain more variance. By doing so, the present study will shed light on the research of the mechanism of the CES-later income relationship and intergenerational income mobility.

\section{Practical implications}

The present study also has some practical implications for individual career development. Firstly, although an individual's later income is influenced by his/her childhood economic status, which seems to demonstrate low intergenerational mobility, this influence is not direct but through the effect of networking ability. The finding that the impact of CES on later income is mediated by networking ability provides critical knowledge for organizations that aim to promote intergenerational mobility. Organizations may treat networking ability as a key intervention point to help individuals from 
low CES households to increase their later income. Specifically, by providing training and a favorable environment to develop individuals' networking ability, their income level in the future will be increased, especially for those low CES individuals.

Second, although previous research has demonstrated that individuals who have a high level of networking ability will be more likely to succeed in performing job tasks and obtain higher income throughout their career (Ferris et al., 2012; Todd et al., 2009), the findings in the current study raises the concern of contextual influence in the networking ability-career success relationship. Individuals should not only focus on their networking abilities but also pay attention to the climate of encouragement of participation in the organization. Without the organization's support for employee participation, high networking ability employees will not be able to fulfill their capacity. From the organizations' point of view, organizations should provide an environment that encourages participation to fully free up individuals' potential for networking. Specifically, organizations could ask employees to participate in management decisions and provide opportunities for employees to suggest improvements in their work. This will help employees to better utilize their networking abilities and in turn, would lead to individuals' higher income levels and career success.

\section{Conclusion}

In summary, the current study draws upon social capital theory (Lin, 1999, 2002) and investigates the mechanisms and contextual moderators of the relationship between CES and later income. The results suggest that networking ability mediates the relationship between CES and later income. In addition, the path of CES to later income via networking ability is stronger when encouragement of participation is high. On the other hand, when encouragement of participation is low, the positive relationship between CES and later income mediated by networking ability is no longer significant. With these findings on the mechanisms and moderators of the CES-later income relationship and suggestions for future directions, the current study sheds some light on the research of intergenerational income mobility.

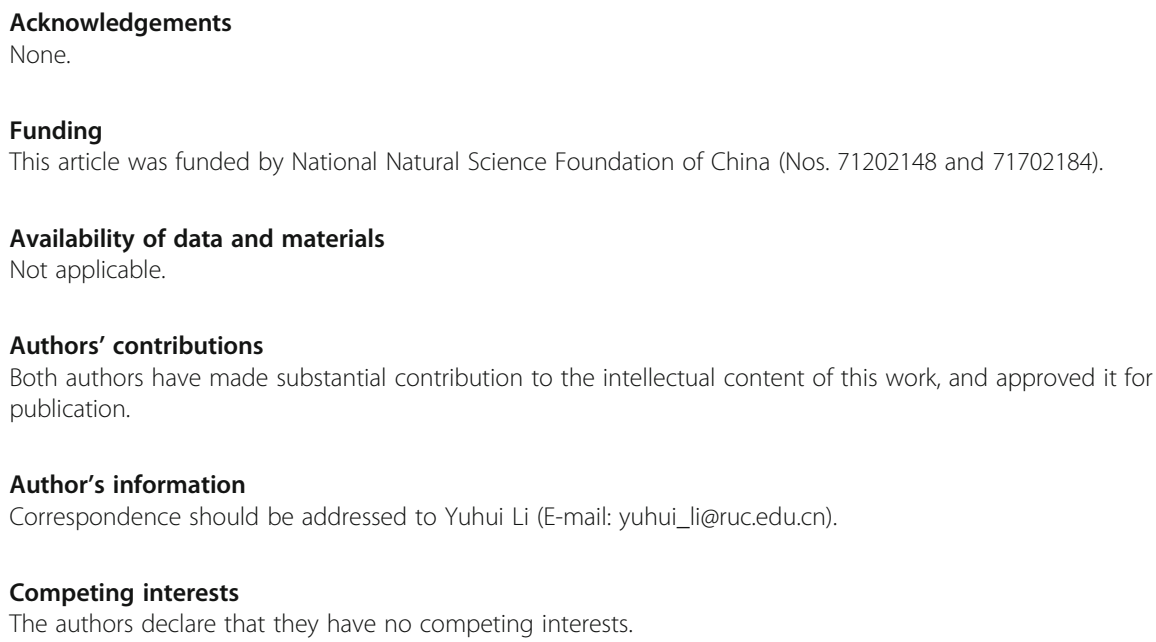


Received: 16 October 2017 Accepted: 3 January 2018

\section{Published online: 20 February 2018}

\section{References}

Bamberger, P. A., Biron, M., \& Meshoulam, I. (2014). Human resource strategy: Formulation, implementation, and impact (2nd ed.). New York, NY: Routledge.

Bamberger, P. A., \& Meshoulam, I. (2000). Human resource strategy : Formulation, implementation, and impact. Thousand Oaks, CA: Sage Publications.

Blickle, G., Kramer, J., Zettler, I., Momm, T., Summers, J. K., Munyon, T. P., \& Ferris, G. R. (2009). Job demands as a moderator of the political skill-job performance relationship. Career Development International, 14, 333-350.

Bourdieu, P. (1986). The forms of capital. In J. G. Richardson (Ed.), Handbook of theory and research of for the sociology of education (pp. 241-258). Westport, CT: Greenwood Press.

Burt, R. S. (2009). Structural holes: The social structure of competition. Cambridge, MA: Harvard university press.

Dreher, G. F. (1977). Nonrespondent characteristics and respondent accuracy in salary research. Journal of Applied Psychology, 62, 773-776.

Duncan, G. J., Yeung, W. J., Brooks-Gunn, J., \& Smith, J. R. (1998). How much does childhood poverty affect the life chances of children? American Sociological Review, 63, 406-423.

Edwards, J. R., \& Lambert, L. S. (2007). Methods for integrating moderation and mediation: A general analytical framework using moderated path analysis. Psychological Methods, 12, 1-22.

Ferris, G. R., Blickle, G., Schneider, P. B., Kramer, J., Zettler, I., Solga, J., et al. (2008). Political skill construct and criterionrelated validation: A two-study investigation. Journal of Managerial Psychology, 23, 744-771.

Ferris, G. R., Treadway, D. C., Brouer, R. L., \& Munyon, T. P. (2012). Political skill in the organizational sciences. In G. R. Ferris \& D. C. Treadway (Eds.), Politics in organizations: Theory and research considerations (pp. 487-529). New York: Routledge/Taylor and Francis.

Ferris, G. R., Treadway, D. C., Kolodinsky, R. W., Hochwarter, W. A., Kacmar, C. J., Douglas, C., \& Frink, D. D. (2005). Development and validation of the political skill inventory. Journal of Management, 31, 126-152.

Ferris, G. R., Treadway, D. C., Perrewé, P. L., Brouer, R. L., Douglas, C., \& Lux, S. (2007). Political skill in organizations. Journal of Management, 33, 290-320.

Gibb, S. J., Fergusson, D. M., \& Horwood, L. J. (2012). Childhood family income and life outcomes in adulthood: Findings from a 30-year longitudinal study in New Zealand. Social Science \& Medicine, 74, 1979-1986.

Hayes, A. F. (2013). Introduction to mediation, moderation, and conditional process analysis: A regression-based approach. New York. NY: Guilford Press.

Hobcraft, J., \& Kiernan, K. (2001). Childhood poverty, early motherhood and adult social exclusion. British Journal of Sociology, 52, 495-517.

Judge, T. A., \& Bretz, R. D. (1992). Political influence behavior and career success. Academy of Management Best Papers Proceedings, 8, 58-62.

Lin, N. (1999). Building a network theory of social capital. Connect, 22, 28-51.

Lin, N. (2002). Social capital: A theory of social structure and action (Vol. 19). New York, NY: Cambridge university press.

Masters, S. H. (1969). The effect of family income on Children's education: Some findings on inequality of opportunity. Journal of Human Resources, 4, 158-175.

Muthén, L. K., \& Muthén, B. O. (2012). Mplus user's guide. Los Angeles,CA: Muthén \& Muthén.

Nahapiet, J., \& Ghoshal, S. (1998). Social capital, intellectual capital, and the organizational advantage. Academy of Management Review, 23, 242-266.

Ng, T. W. H., Eby, L. T., Sorensen, K. L., \& Fieldman, D. C. (2005). Predictors of objective and subjective career success : A meta-analysis. Personnel Psychology, 58, 367-408.

Ng, T. W. H., \& Feldman, D. C. (2014). Subjective career success: A meta-analytic review. Journal of Vocational Behavior, $85,169-179$.

Pfeffer, J. (1992). Managing with power: Politics and influence in organizations. Cambridge, MA: Harvard Business Press.

Preacher, K. J., Rucker, D. D., \& Hayes, A. F. (2007). Addressing moderated mediation hypotheses: Theory, methods, and prescriptions. Multivariate Behavioral Research, 42, 185-227.

Robison, L. J., \& Siles, M. E. (1999). Social capital and household income distributions in the United States: 1980, 1990. The Journal of Socio-Economics, 28, 43-93.

Seibert, S. E., Crant, J. M., \& Kraimer, M. L. (1999). Proactive personality and career success. Journal of Applied Psychology, $84,416-427$.

Seibert, S. E., Kraimer, M. L., \& Crant, J. M. (2001). What do proactive people do? A longitudinal model linking proactive personality and career success. Personnel Psychology, 54, 845-874.

Seibert, S. E., Kraimer, M. L., \& Liden, R. C. (2001). A social capital theory of career success. Academy of Management Journal, 44, 219-237.

Solon, G. (1992). Intergenerational income mobility in the United States. American Economic Review, 82, 393-408

Sun, L. Y., Aryee, S., \& Law, K. S. (2007). High-performance human resource practices, citizenship behavior, and organizational performance: A relational perspective. Academy of Management Journal, 50, 558-577.

Terborg, J. R. (1981). Interactional psychology and research on human behavior in organizations. Academy of Management Review, 6, 569-576.

Thompson, J. A. (2005). Proactive personality and job performance: A social capital perspective. Journal of Applied Psychology, 90, 1011-1017.

Todd, S. Y., Harris, K. J., Harris, R. B., \& Wheeler, A. R. (2009). Career success implications of political skill. The Journal of Social Psychology, 149, 279-304. 